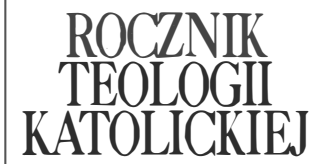

Tom I

Rok 2002

Ks. Krzysztof Nitkiewicz

Watykan

\title{
DUCHOWOŚĆ CHRZEŚCIJAŃSKA W ROZUMIENIU SŁUGI BOŻEGO KS. MICHA£A SOPOĆKI
}

Niełatwo jest podać definicję duchowości chrześcijańskiej, gdyż posiada ona wielorakie formy ukształtowane na przestrzeni wieków pod wpływem charyzmatu świętych oraz uwarunkowań historycznych i kulturowych. Wydaje się jednak, że tym co łączy różne szkoły duchowości, jest pojmowanie jej jako uczestnictwa w misterium Chrystusa i przez to uczestniczenia w misterium całej Trójcy Przenajświętszej z inspiracji i mocą Ducha Św. ${ }^{1}$

Pogląd ten podziela Sługa Boży ks. Michał Sopoćko, kapłan archidiecezji wileńskiej, żyjący w latach 1888-1975, w którego sprawie toczy się obecnie proces beatyfikacyjny na szczeblu Stolicy Apostolskiej². Jego osoba kojarzy się zazwyczaj ze św. Faustyną Kowalską, której był spowiednikiem i kierownikiem duchowym. Sam prowadzący intensywne życie wewnętrzne, przepełnione bezgraniczną ufnością do Boga, zainspirował się jej objawie-

1 Por. M. Dupuy, Spiritualité in Dictionnaire de spiritualité ascétique et mystique doctrine et histoire, Paris 1990, s. 1162; J. Aumann, Teologia spirituale, Roma 1991, s. 16-17; L. Bouyer, Introduzione alla vita spirituale, Roma 1989, s. 14-37.

2 Podczas trwania procesu beatyfikacyjnego, który ma na celu ustalenie heroiczności cnót ks. Sopoćki oraz aprobatę cudu przypisywanego jego wstawiennictwu, przysługuje mu tytuł - Sługi Bożego. W przypadku pozytywnego zakończenia procedury przepisanej prawem, Papież lub Kolegium Biskupów zgromadzonych razem z nim na Soborze Powszechnym, może ogłosić Sługę Bożego - Błogosławionym, co oznacza pozwolenie na jego kult publiczny. Aby mógł być on następnie ogłoszony i czczony w całym Kościele jako Święty, wymagana jest aprobata jeszcze jednego cudu otrzymanego przez jego wstawiennictwo. Por. G. Dalla Torre, Santità e Diritto. Sondaggi nella storia del diritto canonico, Torino 1999, s. 5 i n.; W. Bainert, I Santi nella riflessione della Chiesa, w: Il Culto dei santi oggi, red. tenże, Torino 1985, s. 107. 
niami prywatnymi dotyczącymi prawdy o Bożym Miłosierdziu. W związku z tym przestudiował dogłębnie to zagadnienie w oparciu o Pismo św. i Ojców Kościoła, odgrywając następnie znaczącą rolę w szerzeniu idei oraz kultu Miłosierdzia Bożego. Przyczynił się również do powstania i rozwoju Zgromadzenia Sióstr Jezusa Miłosiernego, mającego wielbić Boga w tajemnicy jego miłosierdzia oraz głosić tę prawdę światu. Kapłańskie życie ks. Sopoćki, związane zasadniczo z trzema miastami: Warszawą, Wilnem i Białymstokiem, wypełniała wieloraka działalność duszpasterska i naukowa. Praca w parafii i w wojsku, na uniwersytecie i w seminarium duchownym, propagowanie trzeźwości, to tylko niektóre dziedziny jakim poświęcał swoje siły i charyzmaty.

Jeżeli chodzi o wspomnianą wcześniej definicję duchowości, mówi on, iż wszystko co dokonało się w Chrystusie, urzeczywistnia się w sposób mistyczny w chrześcijaninie, podkreślając jednocześnie, że przyczyną sprawczą jest tutaj Duch Św. ${ }^{3}$ On prowadzi człowieka do doskonałości, ten z kolei powinien współpracować z Nim, rozwijając w sobie ducha synostwa Bożego otrzymanego na chrzcie św. ${ }^{4}$

To jest podstawą, ponieważ jednak Duch Św. daje każdemu jego własny charyzmat, a nadprzyrodzone życie łaski rozwija się na bazie określonej osobowości, poszczególni mistrzowie życia duchowego kładą nacisk na różne aspekty duchowości chrześcijańskiej. Również Sługa Boży Michał Sopoćko posiada jej własną oryginalną wizję, związaną ściśle z objawieniami prywatnymi św. Faustyny Kowalskiej, a jednocześnie pogłębioną przez długie lata studiów i osobistej refleksji. Będzie ona tematem niniejszego referatu.

\section{Sposób pojmowania Boga}

Według ks. Michała Sopoćki podstawową sprawą w życiu duchowym każdego chrześcijanina jest sposób postrzegania przez niego Boga. Determinuje on bowiem zarówno samą postawę religijną, jak i jej konkretne owoce.

I tak, jeśli widzi się w Bogu tylko surowego władcę i sprawiedliwego sędziego, człowiek nabiera wobec Niego dystansu, staje się formalny i oziębły, uprawiając w stosunku do Stwórcy swoistą politykę w celu otrzymania nagrody.

3 M. Sopoćko, Miłosierdzie Boga w dziełach Jego(dalej MB), Londyn 1959, t. I, s. 22 i n.; tamże, Paryż 1962, t. III, s. 26 i n.

4 Tamże, Paryż 1967, t. IV, s. 33 i n. 
Sługa Boży uważa natomiast, iż „nie tracąc z oczu bojaźni synowskiej i nie zapominając o nagrodzie w wieczności, winniśmy rozbudzić w sobie miłość Boga, która powstaje i wzrasta pod wpływem poznawania Boga jako Ojca Miłosierdzia i Jezusa, jako Najmiłosierniejszego Zbawiciela" 5 .

Owocem tego procesu będzie nadprzyrodzona ufność skierowana ku Bogu, która jest główną dźwignią życia duchowego i najkrótszą drogą do świętości ${ }^{6}$. Stanowi ona jednocześnie klucz do Bożego Miłosierdzia oraz warunek wysłuchania modlitw i otrzymania Bożego błogosławieństwa wraz ze wszystkimi potrzebnymi łaskami?

Należy przypuszczać, że obok wspomnianych już objawień św. Faustyny, duży wpływ na ukształtowanie się takiej opinii wywarła św. Teresa od Dzieciątka Jezus, wyniesiona do chwały ołtarzy 17 maja 1925 r. przez Papieża Piusa XI. Kanonizacja tej francuskiej mistyczki, którą czcimy dzisiaj także jako doktora Kościoła, przyczyniła się do upowszechnienia jej pism i tzw. "Małej drogi" do świętości, w której jednym z pilastrów jest właśnie ufność w Boże Miłosierdzie.

Ks. Sopoćko powołuje się często na św. Teresę, aczkolwiek można dostrzec tu pewną subtelną różnicę jaka zachodzi pomiędzy dwoma autorami.

Św. Teresa z Lisieux opisuje osobiste doświadczenia Bożego Miłosierdzia, wielbi je w przepiękny sposób i wyraża pragnienie, aby mogło być ono poznane przez całą ludzkość. Zauważa zarazem, że „wszystkie dusze nie moga być do siebie podobne, lecz każda winna być swojego rodzaju w celu uczczenia w specjalny sposób poszczególnych Bożych doskonałości"8.

Ks. Sopoćko nie podważa tej opinii, podkreśla jednak, że w przyjęciu prawdy o Bożym Miłosierdziu znajduje się prawdziwy ratunek dla świata i dla każdego pojedyńczego człowieka. Widzi w jej głoszeniu swoje szczególne posłanie i dlatego realizuje je $z$ całym poświęceniem ${ }^{9}$.

Wracając do jego opinii o konieczności uformowania w sobie właściwego oblicza Boga, zaleca on lekturę i medytację Pisma św. Uważa, że spoś-

5 Tamże, s. 34.

6 M. Sopoćko, Potrzeba ufności, WA, 3(1952), 137; MB, II, s. 48.

7 M. Sopoćko, Dziennik (dalej Dz), z. 4, 09.03.1968, 32; M. Sopoćko, Doskonatość a ufność, w: Konferencje ascetyczne, Archiwum Archidiecezjalne w Białymstoku (dalej AAB), t. 44, 52-57; M. Sopoćko, Potrzeba ufności, s. 136-138.

8 Teresa od Dzieciatka Jezus, Rękopis „A”, Ævres complètes, Lonrai 1998, s. 211.

9 Ks. Sopoćko oddaje to w następujących słowach: „Ufność w Miłosierdzie Boże, szerzenie kultu tego miłosierdzia wśród innych i bezgraniczne poświęcenie mu wszystkich moich myśli, słów i uczynków bez cienia szukania siebie będzie naczelną zasadą mego dalszego życia przy pomocy tegoż niezmierzonego miłosierdzia", Dz, z. 2, s. 54 . 
ród wszystkich doskonałości Bożych najczęściej wymienia ono Miłosierdzie: 400 razy czyni to wprost i bardzo często wspomina je pośrednio ${ }^{10}$. Tak więc uważna lektura i medytacja Pisma św. powinna doprowadzić do wniosku, iż w Historii Zbawienia Bóg objawiał się zawsze jako Ojciec Miłosierdzia, przebaczający grzechy, obdarzający łaskami i podtrzymujący człowieka w chwilach prób. Ks. Sopoćko przytacza konsekwentnie wiele cytatów ilustrujących takie właśnie Boże działanie.

Zaleca jednocześnie rozważanie tajemnicy eucharystii, ustanowionej przez Chrystusa z miłosierdzia do ludzi. „Dusza widząc, jak Bóg oddaje się jej całkowicie, nawzajem oddaje się Mu bez zastrzeżeń, nabiera świętego zapału i znajduje szczęście w poświęceniu się, samozaparciu i ofiarnym znoszeniu wszelkich przeciwności" ${ }^{11}$.

\section{Oczyszczenie wewnętrzne}

Człowiek postrzegający w ten sposób Boga, będzie odczuwał potrzebę usunięcia najpotężniejszej przeszkody w relacjach ze Stwórcą, jaką jest grzech, nazywany przez naszego autora „największym i nieskończonym złem". Grzesznik buntuje się przeciw Bogu, obraża Go, a odrywając się od Tego źródła życia nadprzyrodzonego nie może wydać żadnego wartościowego owocu ${ }^{12}$.

Nawrócenie stanowi akt wolnej woli człowieka, ale jest ono ułatwione, czy nawet w pewien sposób sprowokowane przez samego Boga. „Jak ojciec, oczekujący powrotu syna marnotrawnego, tak Miłosierdzie Boże wybiega na drogę i zaprasza grzeszników do siebie przez dobre natchnienia albo przez wyrzuty i niepokoje sumienia"13.

Człowiek powinien się otworzyć na to wołanie i, odczuwając żal za grzechy, a jednocześnie ufność w Boże Miłosierdzie, oczyścić się z grzechów w sakramencie pokuty.

Mając na uwadze zło, które niesie ze sobą grzech, ks. Sopoćko zaleca wzmożenie czujności nad własnym wzrokiem, słuchem i innymi zmysłami oraz nad poruszeniami serca, aby w ten sposób tłumić w zarodku wszelkie pokusy. Ponieważ nie zawsze możliwe jest uczynienie tego o własnych siłach,

\footnotetext{
$10 \mathrm{MB}, \mathrm{I}, \mathrm{s} .15 \mathrm{i} \mathrm{n}$.

11 Tamże, s. 200.

12 MB, III, s. 32-34.

13 Tamże, s. 35.
} 
zachęca do modlitwy o wytrwanie w pokusach, podobnie jak czynili to od najdawniejszych czasów wielcy Ojcowie Kościoła ${ }^{14}$.

Nasz autor podkreśla tu także pożyteczną rolę ascezy, będącej nieustannym poszukiwaniem życia z Bogiem, ciągłym napięciem, jak mówi św. Atanazy Aleksandryjski, które nie zna postojów i nie toleruje ustępstw ${ }^{15}$. Chodzi tu konkretnie o opanowanie namiętności, nieuporządkowanych skłonności oraz przywiązań, jednym słowem wszystkiego, co opóźnia rozwój łaski i w rezultacie przeszkadza pełnemu zjednoczeniu własnej woli $z$ wolą Boga. Dokonuje się to poprzez umartwianie duchowe i fizyczne własnej natury. Człowiek uprawiający ascezę wypełnia ofiarnie i gorliwie wolę Bożą, kierując wszystkie swoje siły ku dobru. Jednocześnie, nawet w przypadku upokorzeń i zapomnienia ze strony innych, zachowuje wewnętrzną pogodę ducha ${ }^{16}$.

\section{Uczestnictwo w życiu Bożym}

Ks. Michał Sopoćko zauważa, iż Bóg Miłosierny udziela swoich łask przede wszystkim w Kościele, gdzie misterium wiary jest nie tylko głoszone, ale i urzeczywistniane. Mówi: „Nikt nie przychodzi do Ojca jak tylko przez Chrystusa (J. 14, 6), ale i nikt nie przychodzi do Chrystusa jak tylko przez Kościół. Nie żyjemy życiem Chrystusa, ani jego duchem, jak tylko w łączności z Kościołem"17.

Z tego powodu Kościołowi należne są szacunek, miłość i posłuszeństwo, a równocześnie należy pozostawać w ścisłej łączności z Chrystusem, który jest jego głową, oraz w jedności z innymi członkami Kościoła wyznającymi prawdziwą wiaręe18.

14 Tamże, s. 38-41; Spośród Ojców Kościoła można tu zacytować św. Jana Chryzostoma, który nauczał, iż „niemożliwym jest, aby ktoś kto się modli popełnił grzech”, zob. Jan Chryzostom, De Anna 4, PG 54, 666ab.

15 Por. J. Roldanus, Le Christ et l'homme dans la théologie d'Athanase d'Alexandrie, Leida 1968, s. 294.

16 MB, I, s. 100, Dz, z. 3, s. 9, z. 4, s. 25, 130.

17 MB, III, s. 213.

18 Tamże, s. 214-216; M. Sopoćko, Poznajmy Boga w Jego Miłosierdziu. Rozważania o Miłosierdziu Bożym na tle litanii, Poznań 1949, s. 119. 


\section{Sakramenty}

Człowiek otrzymuje od Boga życie nadprzyrodzone w sakramentach Kościoła. Są one widzialnymi znakami łaski Bożej i narzędziami, poprzez które spływa ona obficie na wierzących, upodabniając ich do samego Chrystusa i przychodząc im z pomocą w każdej życiowej sytuacji. W związku z tym, nasz autor nazywa sakramenty „dziełem szczególniejszego Miłosierdzia Bożego"19.

Przechodząc z kolei do ich dokładniejszego omówienia, stwierdza, że sakramenty chrztu i pokuty są niejako punktem wyjścia na drodze do doskonałości, wymagającej uwolnienia się od grzechu; są jednocześnie sytuacjami, w których najbardziej ujawnia się Boże Miłosierdzie ${ }^{20}$. Nasz autor nawiązuje tu do starożytnej tradycji kościelnej, według której, jak nauczał między innymi św. Jan Klimak, pokuta jest nowym chrztem" ${ }^{21}$.

Ciekawie brzmią także konkretne wskazania dotyczące obu sakramentów. W pierwszym przypadku, Sługa Boży postuluje, aby każdy chrześcijanin obchodził uroczyście rocznicę swojego chrztu, wielbiąc przy tej okazji Boga za uwolnienienie od grzechu pierworodnego i włączenie w Mistyczne Ciało Chrystusa. Wszyscy razem mieliby natomiast czynić to w pierwszą niedzielę po Wielkanocy, kiedy Liturgia przypomina łaski Bożego Miłosierdzia, podczas gdy w starożytności Niedziela Przewodnia kończyła uroczyście oktawę chrztu przyjmowanego przez katechumenów w Wielką Sobotę 22 .

Ks. Sopoćko podkreśla konieczność przystępowania do sakramentu pokuty, gdyż gładzi on grzechy i zabezpiecza przed nowymi upadkami, obdarza pokojem i przyczynia się do wewnętrznego odrodzenia. Jeżeli chodzi o jego częstotliwość, to w przypadku osób duchownych i konsekrowanych Sługa Boży odsyła do przepisów ówczesnego Prawa Kanonicznego, natomiast "wszystkich wiernych rzetelnie dążących do zharmonizowania władz wewnętrznych" zachęca do spowiedzi przynajmniej co dwa tygodnie ${ }^{23}$.

Także sakrament bierzmowania jest zdaniem naszego autora skutecznym środkiem na pomnożenie łaski uświęcającej, „utwierdzając nad

\footnotetext{
19 Tenże, Poznajmy Boga..., s. 121 i n.

20 Por. MB, III, s. 15-23.

21 Jan Klimak, Scala Paradisi 5, PG 88, 764b.

22 MB, III, s. 220.

23 MB, IV, s. 55-58, $141 \mathrm{i} \mathrm{n}$.
} 
ochrzczonym Boże Miłosierdzie". Jednocześnie Duch Św. uzdalnia bierzmowanego do mężnego wyznawania wiary i życia według jej za$\operatorname{sad}^{24}$.

Ks. Sopoćko poświęca szczególną uwagę eucharystii, mówiąc, iż stanowi ona najpełniejszą formę uczestnictwa w życiu Bożym. Chrystus odnawia w niej misterium Swojej męki i śmierci, jednoczy człowieka z Bogiem oraz udziela mu się jako pokarm duchowy pod postaciami chleba i wina. Jest ona źródłem miłości ku Bogu i ludziom, umacnia i rozwija życie nadprzyrodzone duszy, uzdalnia do gorliwego dokonywania czynów doskonałych i osłabia pokusy ${ }^{25}$.

Mając na względzie te różnorodne owoce eucharystii, Sługa Boży nawołuje do uczestnictwa we Mszy św. i złączenia za każdym razem własnej duchowej ofiary z Najwyższą Ofiarą Chrystusa ${ }^{26}$. Zaleca jednocześnie przystępowanie do Komunii św. sakramentalnej, a w razie niemożliwości, przyjmowanie Komunii św. duchowej27. Jest także gorącym zwolennikiem nawiedzenia i adoracji Najświętszego Sakramentu ${ }^{28}$.

Z eucharystią łączy się bardzo ściśle sakrament kapłaństwa, gdyż jak zauważa ks. Sopoćko „sprawowanie ofiary jest głównym aktem władzy kapłańskiej”. Władza ta „czyni obecnym w Kościele Chrystusa Pana, odradza go w sercach ludzkich przez sakramenty święte i łaski z nich wypływające oraz prowadzi dusze ludzkie do doskonałości. Przez kapłaństwo Chrystus Pan jest nadal wśród nas fizycznie obecny i obdarza nas Miłosierdziem jak za swego życia ziemskiego" 29 .

Sakrament małżeństwa udoskonala miłość małżonków. Ułatwia w ten sposób ich wzajemne współżycie oraz pozwala właściwie wypełniać obowiązki rodzinne i mężnie znosić różne próby ${ }^{30}$.

Ks. Sopoćko mówi, że dzieło sakramentów Bożych byłoby niepełne, gdyby Bóg nie przygotował osobnej pomocy na chwilę śmierci, od której zależy cała wieczność. Jest nią sakrament namaszczenia chorych, pomagający człowiekowi w tym krytycznym momencie dochować ufności w Boże

\footnotetext{
24 MB, III, s. 225-228.

25 Tamże, s. 229 i n., IV, s. 61 i n.

26 MB, II, s. 8.

27 M. Sopoćko, Listy pisane $z$ Czarnego Boru w latach 1942-1943 do pierwszych członkiń organizujacego się Zgromadzenia Zakonnego Miłosierdzia Bożego, Gorzów Wlkp. 1975, s. 30 .

$28 \mathrm{MB}, \mathrm{III}$, s. 230.

29 Tamże, s. $234 \mathrm{i}$.

30 Tamże, s. 239.
} 
Miłosierdzie. Jednocześnie usuwa on grzechy i ich pozostałości, utwierdza w dobrym, a niekiedy nawet przywraca zdrowie ciała ${ }^{31}$.

Człowiek obdarowany sakramentami świętymi, powinien je sobie wysoko cenić, rozumnie $\mathrm{z}$ nich korzystać i dziękować za nie Miłosiernemu Jezusowi. Są one bowiem zgodnie ze słowami Sługi Bożego, wsparciem dla wierzących oraz ich pociechą w życiu i po śmierci ${ }^{32}$.

\section{Modlitwa}

Ks. Sopoćko nazywa modlitwę kluczem otwierającym skarbiec Bożego Miłosierdzia, gdyż Pan Bóg uzależnia od niej udzielenie swojego błogosławieństwa, cnót wlanych i innych darów. Dlatego każdy, kto pragnie rozwijać życie duchowe, powinien się modlić, czyli wznosić swoje myśli i serce ku Bogu. „Modlitwa jest konieczna dla wszystkich: grzeszników i sprawiedliwych - mówi nasz autor. - Bez modlitwy grzesznicy nie zerwą kajdan swych zestarzałych nałogów i nie otrzymają Miłosierdzia Bożego. Bez modlitwy sprawiedliwi nie postąpią na drodze cnoty i nie utrzymają się długo na jej wyżynach, lecz padną niebawem zwyciężeni pokusą ${ }^{33}$.

Cytując wezwania Chrystusa do modlitwy utrwalone na kartach Ewangelii, ks. Sopoćko mówi, że „Słowa te mają moc przykazania Bożego i obowiązują wszystkich w sumieniu. I kto by przez dłuższy czas, np. przez miesiąc, się nie modlił, nie byłby wolny od grzechu śmiertelnego" 34 .

Wzorem modlitwy powinna być dla każdego chrześcijanina modlitwa Jezusa do Ojca, zarówno jeśli chodzi o treść jak i o sposób jej przedstawiania. W tym kontekście ks. Sopoćko zaleca modlitwę ustną, która angażuje całego człowieka oraz modlitwę myślną (rozmyślanie), stanowiącą wyższy stopień obcowania z Bogiem. Postuluje jednocześnie, aby ten kontakt rozciągnąć niejako na cały dzień poprzez odmawianie w różnych okolicznościach aktów strzelistych ${ }^{35}$. Tłumaczy to w następujący sposób: „Pamięć na obecność Bożą uświęca nasze słowa i myśli, uszlachetnia uczynki, udoskonala zmysły i wyobraźnię oraz ułatwia poznawanie naszych grzechów i niedoskonałości w celu przebłagania za nie Boga i uniknięcia ich na przyszłość. Pamięć o obecności Bożej umacnia w walkach, cieszy w cierpieniu, budzi ufność,

31 Tamże, s. 241-244.

32 M. Sopoćko, Poznajmy Boga..., s. 121-123.

33 MB, III, s. 149.

34 MB, II, s. 41.

35 Akty strzeliste są w Kościele katolickim obrządku łacińskiego odpowiednikiem Modlitwy Jezusowej w Kościołach Wschodnich. MB, III, s. 160-164. 
rodzi czystą intencję. Jest jednym z najdoskonalszych sposobów uświęcenia duszy. Ona jest najlepszym środkiem na zły humor, smutek i przygnębienie, albowiem napełnia duszę wielką, niewymowną radością, jest ostoją w niebezpieczeństwach budząc ufność w jego Miłosierdzie"36.

Tymczasem Miłosierdzie Boże samo w sobie powinno być według ks. Sopoćki przedmiotem osobnego nabożeństwa. Pod wpływem prywatnych objawień św. Faustyny i własnych badań, nasz autor postuluje uczczenie go poprzez ustanowienie Uroczystości Najmiłosierniejszego Zbawiciela, następnie poprzez kult obrazu Chrystusa Miłosiernego, odmawianie specjalnej Koronki oraz inne formy pobożności, mające w centrum uwagi ten Boży przy$\operatorname{miot}^{37}$.

Nasz autor wychowany w tradycji wileńskiej, charkteryzującej się żywym nabożeństwem do Matki Bożej Ostrobramskiej - Matki Miłosierdzia, dostrzega także potrzebę pobożności maryjnej. Mówi, iż każdy kto dąży do doskonałości powinien kochać Maryję ogłoszoną przez Chrystusa Matką Miłosierdzia i czcić ją kultem po Bogu Najwyższym, modląc się do niej często. I tu ks. Sopoćko zaleca modlitwę różańcową oraz naśladowanie cnót Najświętszej Matki Zbawiciela ${ }^{38}$.

\section{Praktyka miłosierdzia}

Każdy kto poznał prawdę o Bożym Miłosierdziu i doświadczył jego działania we własnym życiu, powinien być miłosierny względem bliźnich. Nasz autor podkreśla, że wszyscy ludzie są dziećmi jednego Ojca, który kocha każdego miłością miłosierną. Dlatego wskazane jest praktykowanie uczynków miłosiernych nie tylko względem przyjaciół i krewnych, lecz w jednakowej mierze wobec ludzi innych narodów, religii, klas społecznych oraz wrogów i grzeszników.

Ks. Sopoćko, omawiając różne sytuacje, w których powinno być świadczone miłosierdzie, odwołuje się szczególnie do ośmiu błogosławieństw ewangelicznych. Nazywa je, podobnie jak całe Kazanie na Górze: „miłosiernym drogowskazem dla wszystkich ludzi dobrej woli" 39 .

Obok wykonywania konkretnych dzieł miłosierdzia, trzeba unikać wad przeciwnych miłości bliźniego: wrodzonych antypatii, obmowy, upokarzania

\footnotetext{
36 M. Sopoćko, O wszechobecności. Konferencje i kazania duchowe, AAB, t. 34, s. 4.

37 MB, IV, s. 65-79.

38 Tamże, s. 85-94.

39 MB, I, s. 104-107.
} 
innych i zniewagi. W sposób szczególny winno się wystrzegać rzeczy i postaw mogących wywołać zgorszenie i w rezultacie pociągnięcie bliźniego do grzechu.

Jednocześnie należy ćwiczyć postawę pozytywną, dając zawsze dobry przykład i przebaczając doznane urazy.

Nasz autor mówi także o potrzebie praktykowania i rozwijania w sobie innych cnót, teologicznych i moralnych, które są esencjalnym elementem doskonałości chrześcijańskiej. W tej samej perspektywie zaleca otwieranie się na dary Ducha Św., który udziela człowiekowi energii, mocy, oświeceń i natchnień potrzebnych na drodze naśladownictwa Chrystusa i świadczenia o Nim.

Sługa Boży Michał Sopoćko nie ograniczał się do propagowania przedstawionej tu wizji duchowości chrześcijańskiej, ale realizował ją konsekwentnie we własnym życiu. Odzwierciedla ona w wielu miejscach poglądy, które można odnaleźć w podręcznikach ascetycznych oraz dziełach teologicznych Kościoła katolickiego, będących w użytku w czasach mu współczesnych.

Oryginalne jest natomiast przydzielenie centralnego miejsca idei Miłosierdzia Bożego, w którym nasz autor widzi podstawę życia duchowego, zarówno w relacji Boga do człowieka, jak i odwrotnie.

W tym sensie, zachęta ks. Sopoćki do postrzegania Boga jako Ojca Miłosierdzia i pokładania w Nim bezgranicznej ufności, wydaje się być przydatna również obecnie, kiedy pomimo ciągłego postępu w wielu dziedzinach życia, ludzkość odczuwa często różnorodnego rodzaju zagrożenia.

Klarowny wykład pryncypiów doktrynalnych i środków niezbędnych do rozwoju duchowego, będzie jednocześnie pomocą dla osób pragnących prowadzić życie wewnętrzne. Jest to szczególnie aktualne wobec prób tworzenia duchowości nie zainteresowanej poznaniem Prawdy, ale zmierzającej do zapewnienia jednostce choćby krótkotrwałego poczucia autorealizacji i wewnętrznego odprężenia ${ }^{40}$. Ks. Sopoćko przypomina natomiast, że szczęście człowieka ma być trwałe i nieprzemijające, w związku z czym powinien on kierować się zawsze słowami Miłosiernego Zbawiciela: „A to jest życie wieczne: aby poznali Ciebie, jedynego prawdziwego Boga, oraz Tego, którego posłałeś, Jezusa Chrystusa" (J. 17, 3).

40 Niektórzy badacze nazywają ten fenomen spotykany coraz częściej w Europie „duchowością chrześcijańską okresu postmodernistycznego". por. G. Dal Ferro, Spiritualità del post-moderno, w: Quale spiritualità per il terzo millenio, Venezia 2000, s. 7-16; N. Calmès, Les étudiants restent en quête de spiritualité, „La Croix”, 10 grudnia 2001. 